Б. Ю. Комнацький, А. В. Повшенюк, О. О. Коцюра Вінницький національний медичний університет імені М. І. Пирогова

\title{
ОПТИМІЗАЦІЯ ТА РОЛЬ САМОСТІЙНОЇ РОБОТИ СТУДЕНТІВ СТОМАТОЛОГІЧНОГО ФАКУЛЬТЕТУ ЯК ШЛЯХ ДО ПІДВИЩЕННЯ ЯКОСТІ ОСВІТИ
}

\author{
B. Yu. Komnatskyi, A. V. Povsheniuk, O. O. Kotsiura \\ Vinnytsia National Pirogov Memorial Medical University \\ OPTIMIZATION AND ROLE OF INDIVIDUAL STUDENTS' WORK \\ OF DENTISTRY FACULTY AS A WAY TO EDUCATION QUALITY \\ IMPROVEMENT
}

\begin{abstract}
Мета роботи - розробка концепцій ведення самостійної роботи студентів, а також підкреслення ролі викладача у формуванні мотивації до самостійної роботи серед студентів стоматологічного факультету.

Об’єкт дослідження - студенти стоматологічного факультету, предмет дослідження - навчальний процес (самостійна робота студентів) на кафедрі ортопедичної стоматології.

Основна частина. Методики організації самостійної роботи студента ще недостатньо відпрацьовані і являють собою досить нелегку та кропітку роботу. В рамках самостійної роботи бажано проводити діагностичний етап, за допомогою якого виявляється рівень готовності студентів до роботи. Для цього доцільно організувати вихідний контроль знань та умінь студентів-стоматологів з попередніх розділів стоматології, який повинен охоплювати усі основні сторони базисної підготовки, бути максимально об’єктивним і нетривалим у часі. Для раціональної та ефективної самостійної роботи студента потрібно керівництво викладача, а саме безпосереднє навчання студентів основ самостійної роботи.

Висновки. Самостійна робота є однією з форм навчального процесу і $є$ його суттєвою складовою частиною. Планування, управління і контроль є важливими складовими організації самостійної роботи. Для реалізації цих принципів викладач повинен сформувати у студента почуття відповідальності за організацію власного навчання.
\end{abstract}

Ключові слова: самостійна робота студентів; вищий медичний навчальний заклад; навчальний процес; керування; мотивація; цілі; планування.

The aim of the study - to develop the concepts for conducting students' individual work and accentuate teacher's role in the formation of motivation for individual work among students at Faculty of Dentistry.

Object of study - students of Faculty of Dentistry, subject of study - learning process (students' individual work) at the Department of Prosthetic Stomatology.

The main body. Methods of students' individual work still are not enough fulfilled as well as it is difficult and painstaking work. Within the individual work it is desirable to carry out the diagnostic stage by means of which the level of students' readiness to the education process is manifested. For this purpose it is advisable to organize the output control of knowledge and skills on previous branches of the Prosthetic Stomatology among the students of Faculty of Dentistry which should include all major aspects of basic knowledge as well as being the most objective and as short as possible. For the rational and effective students' individual work the teacher's management in needed namely the direct teaching students the basics of individual work.

Conclusion. Students' individual work is one of the most important forms of educational process and is an essential part of it. Planning, management and control are the important components of individual work. For the realization of these principles the teacher should form responsibility for self-learning organization among the students.

Key words: students' individual work; higher medical education institution; education; management; motivation; objectives; planning.

Вступ. Вирішення важливих проблем щодо надання якісної стоматологічної допомоги населенню України можливе лише при забезпеченні лікувальних установ різних форм власності висококваліфі-

() Б. Ю. Комнацький, А. В. Повшенюк, О. О. Коцюра кованими спеціалістами, підготовка яких безпосередньо залежить від організації та діяльності вищих медичних закладів. Проблема вдосконалення професійної підготовки лікаря-стоматолога, або лікаря будь-якої іншої спеціальності, на сьогодні 
розглядається як справа державної ваги, з урахуванням провідних тенденцій, що сформовані в таких нормативних документах, як Закон України “Про вищу освіту”, Національна рамка кваліфікацій, Національна стратегія реформування системи охорони здоров’я в Україні на період 2015-2020 років та ін. Підготовка спеціалістів у вищій школі в сучасних умовах інтеграції України у Європейський освітній простір вимагає уважного ставлення до методики навчання, особливо, якщо мова йде про підготовку медичного фахівця. Організація навчального процесу студентів стоматологічного факультету повинна сприяти ефективному засвоєнню теоретичних знань, вмінь та практичних навичок, стимулювати до систематичного навчання, а також до посилення мотивації. Сучасна система вищої освіти набуває значних змін: кількість аудиторних годин скорочена, а частка годин самостійної роботи студентів значно зросла. Впровадження кредитномодульної системи навчання стимулює студентів до більш ефективного самонавчання. Систематизація теоретичного та практичного досвіду самостійної позааудиторної роботи в сучасному вищому навчальному закладі переконує у тому, що вона є невід’ємною частиною навчального процесу.

Мета роботи - розробка концепцій ведення самостійної роботи студентів, а також підкреслення ролі викладача у формуванні мотивації до самостійної роботи серед студентів стоматологічного факультету.

Об’єкт дослідження - студенти стоматологічного факультету, предмет дослідження - навчальний процес (самостійна робота студентів) на кафедрі ортопедичної стоматології ВНМУ ім. М. І. Пирогова.

Основна частина. Самостійна робота студентів (CPC) - це навчальна діяльність, яка планується, виконується за завданням, під методичним керівництвом і контролем викладача, але без його прямої участі [1]. Цілеспрямовано організована самостійна робота студентів дозволяє створити необхідні умови для формування сумлінного ставлення до навчальної роботи студента, виховання почуття обов’язку і відповідальності, працездатності та ініціативності, наполегливості і дисциплінованості, а також творчого начала та інших етичних норм, необхідних для гідного виконання у професійній діяльності [2]. Під час виконання самостійної роботи відбувається не тільки закріплення та поглиблення знань з дисципліни, але й активне, цілеспрямоване вивчення нового матеріалу, набуття студентом нових знань та умінь без безпосередньої участі у цьому процесі викладача.

Навчальний час, відведений для самостійної роботи студента, регламентується робочим навчальним планом і повинен становити не менше 1/3 та не більше 2/3 загального обсягу навчального часу студента з розрахунку 30 годин на тиждень (згідно з положенням про організацію навчального процесу у ВНМУ ім. М. І. Пирогова).

Проблема ефективної організації самостійної роботи студентів, виховання у студентів потреби постійно самостійно працювати над підвищенням якості знань, вдосконалення професійних умінь i навичок була і залишається актуальною, адже залежить від багатьох факторів. Основними показниками рівня підготовленості студента до самостійної роботи можуть бути: вміння планувати свою діяльність, бачити варіативні шляхи досягнення поставленої мети і знаходити оптимальний з них; володіння швидкісним читанням; вміння аналізувати та виділяти головну позицію в здобутій інформації; навички компактного, скороченого подання інформації, якою володієш; вміння виконувати різні види фіксації отриманої інформації (тези, виписки, цитування та ін.); дотримання вимог оформлення бібліографії тощо.

Слід відмітити, що методики організації самостійної роботи студента ще недостатньо відпрацьовані і являють собою досить нелегку та кропітку роботу. Деякі автори у своїх дослідженнях вказують на те, що шкільні методи самостійної роботи малопридатні для системи навчання у ВНЗ, а отже і для студентів. 3 першого дня перебування у вищому навчальному закладі їх потрібно навчати систематично та самостійно працювати в аудиторії та у бібліотеці, щоб вони якомога швидше могли оволодіти навичками самостійної навчальної діяльності [3]. Студенти, які навчаються у вищих медичних навчальних закладах, особливо на перших курсах, як правило, мають недостатні навики ведення самостійної роботи, що, в свою чергу, може призводити до розвитку ментальної кризи успішності та компетентності. Саме тому організація викладачем самостійної роботи повинна надати цим адаптаційним кризам керований характер і стимулювати формування у студентів мотивації до навчання [4]. Тому в рамках самостійної роботи бажано передбачати діагностичний етап, за допомогою якого виявляється рівень готовності студентів до роботи. Для цього доцільно організувати вихідний контроль знань та умінь 
студентів-стоматологів 3 попередніх розділів стоматології (пропедевтика, матеріалознавство і т. д.) та інших фундаментальних дисциплін з метою виявлення розділів і тем, з яких вони мають недостатні знання, для того щоб превентивно уникнути ускладнення при вивченні дисципліни в подальшому. Вихідний контроль, як правило, повинен плануватися та проводитися на першому занятті на початку вивчення кожного розділу дисципліни. Оптимальними формами і методами проведення його є тестування або програмоване опитування. Вихідний контроль повинен охоплювати усі основні сторони базисної підготовки, бути максимально об’єктивним і нетривалим у часі.

Значні психологічні ускладнення в дидактичній і навчально-професійній адаптації студентів перших курсів мають мотиваційний характер. Низька мотивація пов’язана 3 недостатнім уявленням про свою майбутню професійну діяльність. Студенти-стоматологи часто не прослідковують зв'язок основних положень дисциплін, які ними вивчаються, з майбутньою практичною діяльністю. Це зумовлено в тому числі тим, що професійне навчання і практична діяльність у навчальних планах ВНЗ розведені в часі. Спочатку, протягом двох років, студент вивчає базові медичні науки та адаптується у ВНЗ, і тільки на третьому курсі студенти проходять літню виробничу практику з терапевтичної стоматології, на четвертому - з ортопедичної, таким чином входячи в самостійну практичну діяльність. Тому варто відмітити доцільність вивчення студентами-стоматологами вимог щодо ведення медичної документації на відповідних етапах і правовий захист лікарів-стоматологів. Окрім того, включення питань біоетики та медичної деонтології при підготовці лікарів-стоматологів є важливою умовою розвитку студентів, формування їх свідомості як фахівців.

Організація самостійної роботи повинна бути спрямована на розв’язання двох взаємозалежних завдань:

1) розвиток у студентів самостійності у пізнавальній діяльності;

2) вміння студентів самостійно використовувати знання у навчанні та практичній діяльності.

Для раціональної та ефективної самостійної роботи студента потрібно керівництво викладача. Воно полягає, перш за все, у плануванні самостійної роботи студентів. Викладач повідомляє студентам основні завдання, які виносяться для самостійного опрацювання під час вивчення конкретної теми. Наступним етапом керівництва са- мостійною роботою повинно бути формування у студентів потреб і мотивів до активної та творчої самостійної роботи, адже навчальна діяльність без мотивації - мало- або неефективна. Зазвичай формування мотивації здійснюється зусиллями викладача через пояснення важливості навчання для майбутньої діяльності. Проте, без зворотної позитивної реакції студентів, навчальний процес втрачає ефективність. Важливим є також підвищення самооцінки студентів, адже вона позитивно впливає на інші функції навчання: засвоєння знань, формування вмінь та навичок, підвищення творчого потенціалу. Найважливішим завданням викладача є безпосереднє навчання студентів основ самостійної роботи. При цьому студента потрібно навчити правильно організовувати самостійну роботу, чітко формулювати завдання. Звичайно ж, в сучасних умовах глобалізації та розвитку комунікацій, самостійна робота студентів дуже часто пов’язана з використанням мережевих технологій та знанням англійської мови. Комп’ютерні мережі у сфері самостійної роботи студентів надають їм можливість працювати з електронними бібліотеками, міжнародними наукометричними базами, новітніми освітніми і навчальними програмами, використовувати спеціалізовані банки даних i знань тощо.

Завершальним етапом повинно бути проведення контролю за виконанням поставлених завдань. Необхідним кроком є визначення рівня засвоєного матеріалу, потрібного для вивчення нового. Контроль та облік знань має різні функції. Зокрема, навчальна - полягає в удосконаленні та систематизації знань, які перевіряються; головна мета контролюючої функції - облік стану знань та умінь студентів на конкретному етапі навчання; виховна - сприяє розвитку у студента почуття відповідальності за свою власну навчальну діяльність, формуванню високоморальних якостей, вихованню чесності, відповідальності. Контроль і оцінка знань мають також важливі методичні функції, такі, як: розвиток у студентів логіки та ерудиції, покращення короткотривалої та довготривалої пам’яті, виявлення, усунення та аналіз допущених помилок.

Висновки. Самостійна робота є однією з форм навчального процесу і $є$ його суттєвою складовою частиною. Планування, управління і контроль $є$ важливими складовими організації самостійної роботи. Для реалізації цих принципів викладач повинен сформувати у студента почуття відповідальності за організацію власного навчання. 
Перспективи подальших досліджень полягають у розробці та адаптації серед студентів-стоматологів схеми ведення самостійної роботи, а також пошуку нових методів і форм керування самостійною роботою.

\section{Список літератури}

1. Звонников В. И. Инновационные методы оценки учебных достижений студентов / В. И. Звонников // Высшее образование. - 2006. - № 5. - С. 12-17.

2. Медична освіта у світі та в Україні / Ю. В. Поляченко, В. Г. Передерій, О. П. Волосовець [та ін.]. - К. : Книга плюс, 2005. - 383 с.

3. Підкасистий І. Ф. Педагогічні технології : навч. посіб. / І. Ф. Підкасистий, І. Ф. Прокопенко, В. І. Євдо-

\section{References}

1. Zvonnikov, V.I. (2006). Innovatsionnyye metody otsenki uchebnykh dostizheniy studentov [Innovative methods of students' educational achievements evaluation]. Vyssheye obrazovaniye - Higher education, 5, 12-17 [in Russian].

2. Poliachenko, Yu.V., Perederii, V.H., \& Volosovets, O.P. (2005). Medychna osvita u sviti ta v Ukraini [Medical Education around the world and in Ukraine]. K.: Knyha plius [in Ukrainian].

3. Pidkasystyi, I.F., Prokopenko, I.F., \& Yevdokymov, V.I. (2006). Pedahohichni tekhnolohii: navchalnyi posibnyk кимов ; за заг. ред. І. Ф. Прокопенко. - Х. : Колегіум, 2006. - 224 с.

4. Слободчиков В. И. Основы психологической антропологии. Психология развития человека. Развитие субъективной реальности в онтогенезе : учебное пособие для вузов / В. И. Слободчиков, Е. И. Исаев. - М. : Школьная пресса, 2000. - 416 с.

[Pedagogical Technologies: Study Guide]. Kharkiv: Kolehium [in Ukrainian].

4. Slobodchikov, V.I., \& Isayev, E.I. (2000). Osnovy psikhologicheskoy antropologii. Psikhologiya razvitiya cheloveka. Razvitiye sub"yektivnoy real'nosti v ontogeneze: uchebnoye posobiye dlya vuzov [Fundamentals of psychological anthropology. Psychology of human evolution. Evolution of subjective reality in ontogenesis: Study guide for universities]. M.: Shkolnaya pressa [in Russian]. 